\title{
Peru's national folic acid fortification program and its effect on neural tube defects in Lima
}

\author{
Daniel J. Ricks, ${ }^{1}$ Chris A. Rees, ${ }^{1}$ Katharine A. Osborn, ${ }^{1}$ \\ Benjamin T. Crookston, ${ }^{2}$ Katherine Leaver, ${ }^{1}$ Samuel B. Merrill, ${ }^{3}$ \\ Carlos Velásquez, ${ }^{4}$ and Jane H. Ricks ${ }^{1}$
}

Suggested citation

Ricks DJ, Rees CA, Osborn KA, Crookston BT, Leaver K, Merrill SB, et al. Peru's national folic acid fortification program and its effect on neural tube defects in Lima. Rev Panam Salud Publica. 2012;32(6):391-8.

\begin{abstract}
Objective. To evaluate the impact of Peru's national folic acid fortification program on folic acid content in wheat flour, and the effect on birth prevalence of neural tube defects (NTDs) in Lima, and to compare the program's legislative requirements with international standards. Methods. Bread was sampled from six sites across Peru and tested for folic acid. Data were obtained from the largest obstetric hospital in Lima on the prevalence of births (live and still) with NTDs during both the pre-fortification period (2004-2005) and post-fortification years (2007-2008).

Results. Folic acid content in the sampled bread met national legislative requirements but was less than one-half of the level recommended for Peru by the World Health Organization (WHO) (2.6 mg/kg wheat flour). Birth prevalence of NTDs was 18.4/10 000 in the pre-fortification period and 20.0/10 000 during post-fortification years. Relative risk for NTDs after fortification was 1.02 (95\% confidence interval 0.77-1.35, $\mathrm{P}=0.90$ ).

Conclusions. Peruvian legislative requirements for folic acid fortification are below international (WHO) recommendations; birth prevalence of NTDs in Lima is higher than international benchmarks; and no decrease in NTDs following fortification of flour with folic acid (according to Peruvian national standards) was observed. As increasing the level of folic acid in flour remains the most sustainable way of preventing NTDs, it is recommended that Peru increase its folic acid fortification requirements to meet those recommended by WHO $(2.6 \mathrm{mg} / \mathrm{kg})$.
\end{abstract}

Key words Neural tube defects; folic acid; food, fortified; public policy; Peru.

Neural tube defect (NTD) spectrum (failure of the embryonic neural tube to close properly) is the most common congenital defect of the central nervous sys-

\footnotetext{
${ }^{1}$ University of Utah, Salt Lake City, Utah, United States of America. Send correspondence to: Daniel J. Ricks, daniel.ricks@utah.edu

2 Brigham Young University, Provo, Utah, United States of America.

${ }^{3}$ Utah State University, Logan, Utah, United States of America.

${ }^{4}$ Oficina de Cooperación Científica Internacional, Instituto Nacional Materno Perinatal, Lima, Peru.
}

tem (1), affecting the brain and/or spinal cord of 300000 newborns worldwide each year $(2,3)$. NTDs usually occur in either the lower back or the cranium. Upper NTDs (those occurring at the 11th thoracic vertebra and above) can cause complete failure of the brain to develop (anencephaly), encephalocele, and other less common disorders. Spina bifida is the most common NTD of the lower spinal cord. Anencephaly is fatal at or within hours of birth. For a child born with an NTD other than anencephaly to survive infancy, pediatric neurosurgery is required in all but the most minor cases. Even with successful surgery, the life of the child is permanently affected. Children with spina bifida often remain paraplegic for life, develop hydrocephalus, suffer gastrointestinal and genitourinary problems, and have a shortened life expectancy (4).

Global birth prevalence of NTDs ranges from 5.5/10000 (in the United States) (5) to as high as 82.1/10 000 (in 
parts of India) (6). Fortunately, it is estimated that $49 \%-85 \%$ of NTDs (spina bifida and anencephaly) are preventable (7) if women have sufficient metabolic stores of folic acid prior to conception $(8,9)$. These cases are known as FAPSBA (folic acid-preventable spina bifida and anencephaly) (9). Prevention can be achieved on a small scale through vitamin supplementation prior to conception (4). However, supplementation programs have been unsuccessful both on a large scale and over a sustained period (10). Fortification of wheat flour with folic acid at the production level has been shown to be a sustainable method for improving folic acid levels on a national level (9-11).

Currently 61 countries fortify their wheat flour with folic acid, one country fortifies its maize flour with folic acid, and six countries fortify both their maize flour and wheat flour (9). In addition to this study, studies have been conducted in eight countries to evaluate the change in prevalence of NTDs before and after fortification $(5,11-17)$ (Table 1). Of the eight previous studies, seven found a statistically significant decrease in NTDs with fortification. Saudi Arabia observed a $60 \%$ reduction in the prevalence of NTDs (from 19/10 000 to 7.6/10 000) (11). Brazil showed no significant change and no downward trend in NTDs. Further studies are expected to elucidate the consequence of fortification in Brazil (13).

NTDs are largely preventable through fortification of flour with folic acid. Prevention of NTDs helps improve the health of a population while concurrently creating financial savings to the

TABLE 1. Rate of neural tube defects (NTDs) a per 10000 births before and after folic acid fortification of wheat flour, percent change, fortification level, year of study, and source, various countries, 1997-2005

\begin{tabular}{|c|c|c|c|c|c|c|}
\hline \multirow[b]{2}{*}{ Country } & \multicolumn{2}{|c|}{ Rate per 10000 births } & \multirow[b]{2}{*}{$\begin{array}{c}\text { Change } \\
(\%)\end{array}$} & \multirow{2}{*}{$\begin{array}{l}\text { Fortification level } \\
\text { (ppm; mg folic } \\
\text { acid/kg flour) }\end{array}$} & \multirow[b]{2}{*}{$\begin{array}{c}\text { Year } \\
\text { of study }\end{array}$} & \multirow[b]{2}{*}{ Source } \\
\hline & $\begin{array}{c}\text { Before } \\
\text { fortification }\end{array}$ & $\begin{array}{c}\text { After } \\
\text { fortification }\end{array}$ & & & & \\
\hline Argentina & 32.1 & 17.6 & -45 & 2.2 & 2003 & (12) \\
\hline Brazil & $7.2^{b}$ & $5.1^{\mathrm{b}}$ & $N S^{c}$ & 1.5 & 2004 & (13) \\
\hline Canada & 15.8 & 8.6 & -46 & 1.5 & 1998 & (14) \\
\hline Chile & 17.0 & 10.1 & -40 & 2.2 & 2000 & (15) \\
\hline Costa Rica & $9.7^{b}$ & $6.3^{b}$ & -35 & 1.8 & 1997 & (16) \\
\hline Peru & 19.7 & 20.0 & NS & 1.2 & 2005 & \\
\hline Saudi Arabia & $19.0^{\mathrm{b}}$ & $7.6^{\mathrm{b}}$ & -60 & 1.5 & 2001 & (11) \\
\hline South Africa & 14.1 & 9.8 & -30.5 & 1.5 & 2003 & (17) \\
\hline United States & 7.6 & 5.5 & -26 & 1.4 & 1998 & (5) \\
\hline
\end{tabular}

a Spina bifida, anencephaly, and encephalocele.

b Per live births.

${ }^{c}$ NS: not statistically significant.

health care system. Treating NTDs requires the participation of neurosurgeons, pediatric urologists, pediatric anesthesiologists, pediatric rehabilitation professionals, and other specialists who may not exist in sufficient quantities in many countries. In the United States, the lifetime cost for caring for a child with spina bifida has been estimated at US\$ 319000 (18). In Chile, the estimated lifetime cost is US\$ 87000 . The cost of Chile's national folic acid fortification is US\$ 275000 per year and prevents 103 cases of spina bifida annually. Financially this translates into a US\$ 9 million cost savings or US\$33 saved for every US\$ 1 spent on fortification (19).

In 2006, Peruvian legislators ratified a bill to fortify wheat flour with folic acid at $1.2 \mathrm{mg}$ folic acid $/ \mathrm{kg}$ wheat flour $(1.2 \mathrm{mg} / \mathrm{kg}$ ) (20). The expected result of this legislation was a $25 \%$ decrease in NTDs (9).

The purpose of this study was to evaluate the impact of Peru's folic acid legislation on the folic acid content in bread, and the effect on prevalence of live/still births with NTDs in Lima, and to compare Peru's fortification program with international standards.

\section{MATERIALS AND METHODS}

\section{Folic acid fortification measurements}

Bread was sampled through random sampling and folic acid levels were measured for six samples of wheat bread. Two samples were obtained (" $\mathrm{A}$ " and " $\mathrm{B}$ ") in each of the three cities in which the University of Utah (Salt Lake City, UT, USA) has collaborative research re- 
analyzed. For the purposes of this report, the years from 2004-2005 were designated as "pre-fortification" and the years from 2007-2008 as "post-fortification."

Statistical analyses were conducted using SAS statistical software (version 9.2, Cary, NC, USA). The birth prevalence is reported for each diagnosis for both the pre- and post-fortification periods. Relative risks and 95\% confidence intervals (CIs) were calculated for spina bifida, anencephaly, and encephalocele comparing pre- and post-fortification rates.

To further validate the findings and examine for underlying trends, a runtime control chart was generated using data from all newborns with discharge diagnoses of NTDs. The run-time-averaged chart included control limits of \pm 3 standard deviations.

\section{Comparison to South American fortification programs}

To create a context in which to evaluate the Peruvian fortification program (23), a literature review of the programs of other South American countries was conducted, and the international guidelines established by the World Health Organization (WHO), based on each country's average daily flour consumption (24), were obtained. Published reports of flour consumption by country throughout South America, levels of fortification in each country, and change in NTDs in each country since fortification, where available, were analyzed. Comparisons were then made between countries of levels of fortification, and within each country between the WHO recommendations for fortification and the actual level of fortification required by law.

The institutional review board of the University of Utah approved the human research portion of the study prior to its initiation. Permission was also obtained from INMP's Ethics Committee. Anonymity of the data was guaranteed by the electronic database. The data were mined from the database by ICD-10 code and delivered to the researchers with no patient-identifiable data.

\section{RESULTS}

Folic acid assays performed on six Peruvian bread samples yielded levels of folic acid from $1.21 \mathrm{mg} / \mathrm{kg}$ to $2.19 \mathrm{mg} / \mathrm{kg}$, with an average level of $1.78 \mathrm{mg} / \mathrm{kg}$. The results were as follows: Huaraz "A," $1.21 \mathrm{mg} / \mathrm{kg}$; Huaraz "B," $2.01 \mathrm{mg} / \mathrm{kg}$; Lima "A," 1.98 mg/kg; Lima "B," 1.72 mg/kg; Trujillo "A," $2.19 \mathrm{mg} / \mathrm{kg}$; and Trujillo "B," $1.56 \mathrm{mg} / \mathrm{kg}$. In all of the samples, the level of folic acid was higher than Peru's legislative requirement of $1.2 \mathrm{mg} / \mathrm{kg}$ (23) (Figure 1).

During the pre-fortification period there were 38503 total births at the INMP, including 40 cases of spina bifida (10.4/10 000), 29 cases of anencephaly (7.5/10 000), and 2 cases of encephalocele $(0.5 / 10000)$, for a total of 71 NTDs. The birth prevalence of NTDs during the pre-fortification period was 18.4/10 000 total births. During post- fortification years there were 35974 total births at the hospital, with 62 cases of spina bifida (17.2/10 000), 10 cases of anencephaly $(2.8 / 10000)$, and 0 cases of encephalocele $(0 / 10000)$, for a total of 72 NTDs. The birth prevalence of NTDs in the post-fortification years was 20.0/10 000 total births.

As noted in Table 2, when comparing the pre- and post-fortification periods, the birth prevalence of spina bifida increased by $59 \%$ (relative risk [RR] 1.59, 95\% CI 1.15-2.22); anencephaly decreased by $64 \%$ (RR 0.36, 95\% CI 0.18-0.70); and the birth prevalence of encephalocele decreased by $100 \%$ (RR 1.00, 95\% CI 1.00-1.00). The overall birth prevalence of NTDs increased 2\% (RR 1.02, 95\% CI 0.77-1.35).

The period from 2001 to 2008 showed no significant difference in the birth prevalence of NTDs at INMP. The runtime-averaged chart revealed an average control limit (CL) of 19.5 NTDs per 10000 births, with an upper control limit (UCL) of 26.6 and a lower control limit (LCL) of 12.5. There were no significant trends (three or more data points trending the same direction) or changes (data points outside the upper or lower control limits) before or after implementation of the fortification laws (Figure 2).

\section{DISCUSSION}

These results demonstrate that, although folic acid fortification of wheat flour in Peru is meeting national legislative requirements, children born at the INMP did not experience the decrease

\begin{abstract}
FIGURE 1. Folic acid fortification levels $(\mathrm{mg} / \mathrm{kg}$ ) recommended by the World Health Organization and required by Peruvian law versus those found in six samples of wheat bread collected from three cities (Huaraz, Lima, and Trujillo), Peru, 2009
\end{abstract}

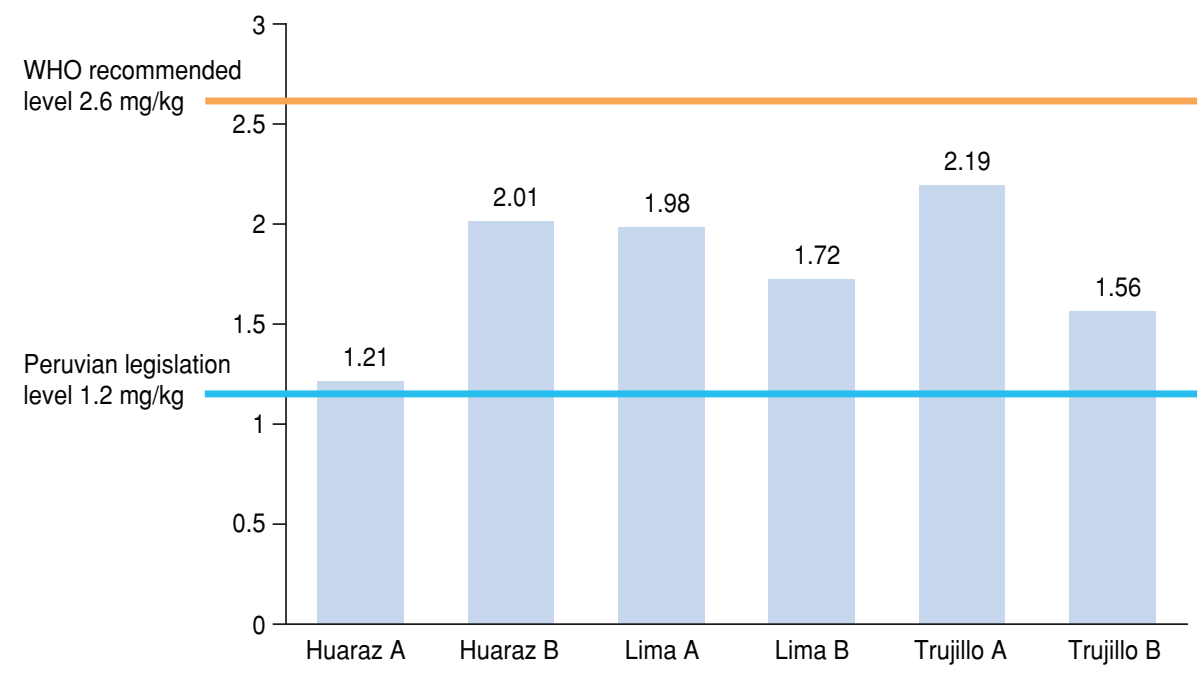


TABLE 2. Rate of neural tube defects (NTDs) per 10000 births $^{\mathrm{a}}$ before and after folic acid fortification of wheat flour, percent change, relative risk, Lima, Peru, 2001-2008

\begin{tabular}{|c|c|c|c|c|c|c|c|}
\hline \multirow[b]{2}{*}{ Type of NTD } & $\begin{array}{c}\text { Number of diagnoses } \\
\quad(n=75749)\end{array}$ & $\begin{array}{c}\text { Rate per } \\
10000 \text { births }\end{array}$ & $\begin{array}{l}\text { Number of diagnoses } \\
\qquad(n=35974)\end{array}$ & $\begin{array}{c}\text { Rate per } \\
10000 \text { births }\end{array}$ & \multirow{2}{*}{$\begin{array}{l}\text { Change } \\
(\%)\end{array}$} & \multirow{2}{*}{$\begin{array}{c}\text { Relative risk } \\
\left(95 \% \mathrm{Cl}^{\mathrm{b}}\right)\end{array}$} & \multirow[b]{2}{*}{$P$} \\
\hline & \multicolumn{2}{|c|}{ Before fortification } & \multicolumn{2}{|c|}{ After fortification } & & & \\
\hline All studied ${ }^{c}$ & 149 & 19.7 & 72 & 20.0 & +2 & $\begin{array}{c}1.02 \\
(0.77-1.35)\end{array}$ & 0.9037 \\
\hline Spina bifida & 82 & 10.8 & 62 & 17.2 & +59 & $\begin{array}{c}1.59 \\
(1.15-2.22)\end{array}$ & 0.0053 \\
\hline Anencephaly & 59 & 7.8 & 10 & 2.8 & -64 & $\begin{array}{c}0.36 \\
(0.18-0.70)\end{array}$ & 0.0016 \\
\hline Encephalocele & 8 & 1.1 & 0 & 0.0 & -100 & $\begin{array}{c}1.00 \\
(1.00-1.00)\end{array}$ & 0.0513 \\
\hline
\end{tabular}

a Live births and stillbirths.

b Cl: confidence interval.

c Spina bifida, anencephaly, and encephalocele.

in NTDs that has been found in other nations with mandated fortification of wheat flour with folic acid.

Peru's average daily wheat flour consumption per capita is estimated at 104 $\mathrm{g}$ /day (25). For this level of wheat flour consumption, WHO recommends folic acid fortification with $2.6 \mathrm{mg} / \mathrm{kg}(24)$ to achieve the current recommendations that women of childbearing age consume $0.4 \mathrm{mg}$ of folic acid daily to decrease the risk of NTDs (26-28). Thus, Peru's fortification law of $1.2 \mathrm{mg} / \mathrm{kg}$ (23) is less than one-half of the recommended fortification level. Also, when compared to all other countries with laws requiring fortification, Peru's fortification is the fifth-lowest level of any fortifying nation in the world (9) and the third-lowest in the western hemisphere, with only Mexico and Ecuador ranking lower.

\section{Limitations}

This study had several limitations. First, Peru currently does not have a national birth defect surveillance system and data on NTDs can only be obtained by petitioning individual hospitals. The data reported here come from a single major hospital in an urban area and may not be representative of the entire country. This limitation is not unique to this study, however, as all pre- and postfortification analyses conducted outside North America were based on data from a single hospital or city database. While this type of sampling has inherent bi- ases, it is the current best practice for countries without comprehensive national databases. In addition, this study was conducted at a referral hospital. Therefore, the number of birth defects found in the study may have been inflated by antenatal referrals for high-risk pregnancies. Pre- and post-fortification comparisons should be considered valid, however, as INMP policy, documentation, and data storage systems were not altered throughout the study period.

Second, this study was carried out at an urban health facility. Differences between rural and urban settings in the proportion of total caloric consumption of wheat flour and tuber roots are well established $(29,30)$. This leads to variations in nutritional status and con-

FIGURE 2. Run-time-averaged control chart showing prevalence of in-hospital neural tube defects (NTDs) per 10000 births (live and still), including trend line, average, upper control limit (UCL), and lower control limit (LCL), Lima, Peru, 2001-2008

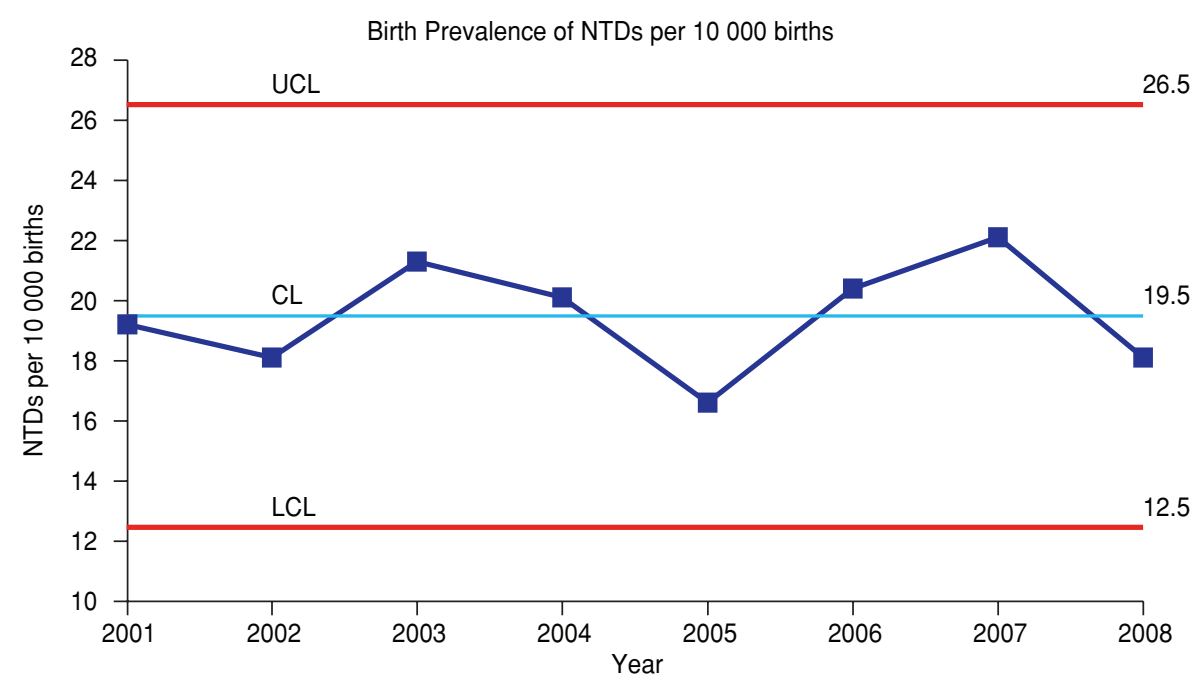


sumption of fortified foods. However, in South America, urban populations consume more wheat flour than populations in rural areas, where more tubers are grown and consumed. Therefore, if no drop in NTDs was found in Lima following the fortification program, it could be assumed that there was no improvement in the rural areas of the country either.

Third, while the overall birth prevalence of NTDs did not change pre- and post-fortification, the birth prevalence of spina bifida increased, and the reason for this is not known. Possible explanations include an increase in patients referred to INMP from the catchment area, or an absolute increase in the birth prevalence of spina bifida within the population throughout the study period. According to INMP, however, patient referral patterns (along with ultrasound methods at its facility and the referring hospitals) have not changed over the past 10 years.

\section{Strengths}

This study had four key strengths. The first two were a direct result of the study site. As the largest maternity hospital in Peru, INMP is responsible for nearly 3\% of all Peruvian births. This large sample of the population was ideal for analyzing uncommon conditions such as NTDs. In addition, INMP's methods for diagnosis and data recording, storage, and analysis were established seven years prior to the initiation of the retrospective study, which ensured internal data consistency throughout the study period. The third and fourth strengths were the fact that this study was the first to test and report bread fortification levels in Peru, and it used the first Peruvian data on preand post-fortification birth prevalence of NTDs.

A recent paper by Tarqui-Mamani et al. investigated pre-fortification levels of NTDs at INMP from 2001-2005 based on hospital chart review (31). The study found an average rate of 13.6 NTDs per 10000 births. While slightly lower than the rate found in the current study, this finding confirms that pre-fortification levels of NTDs among newborns in Peru are relatively high compared to other countries that fortify their wheat flour with folate. Both studies demonstrate NTD prevalence significantly higher than the rate of 5/10 000 expected in a population with a well-fortified diet (32).

The question remains as to why there was no difference before and after folic acid fortification. The authors' hypothesis is that women of childbearing age are not getting enough folic acid in their diet. In the aforementioned study from Brazil (13), there was no downward trend or statistical difference in NTD prevalence pre- and post-fortification, similar to what was found in this study. In both Brazil and Peru, folic acid fortification levels of wheat flour are lower than that recommended by $\mathrm{WHO}$, whereas in all but one of the countries with published studies that showed statistically significant decreases in NTDs, fortification levels are higher than those recommended by WHO (Figure 3 ). The one country that fortifies wheat flour at a lower rate than recommended by WHO yet still has shown a decrease in NTDs is Costa Rica. Costa Rica is the only country in Central and South America with mandatory folic acid fortification of four foods:

FIGURE 3. Folic acid wheat flour fortification levels $(\mathrm{mg} / \mathrm{kg})$ required by law, versus World Health Organization (WHO) recommendations, and

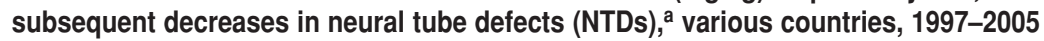

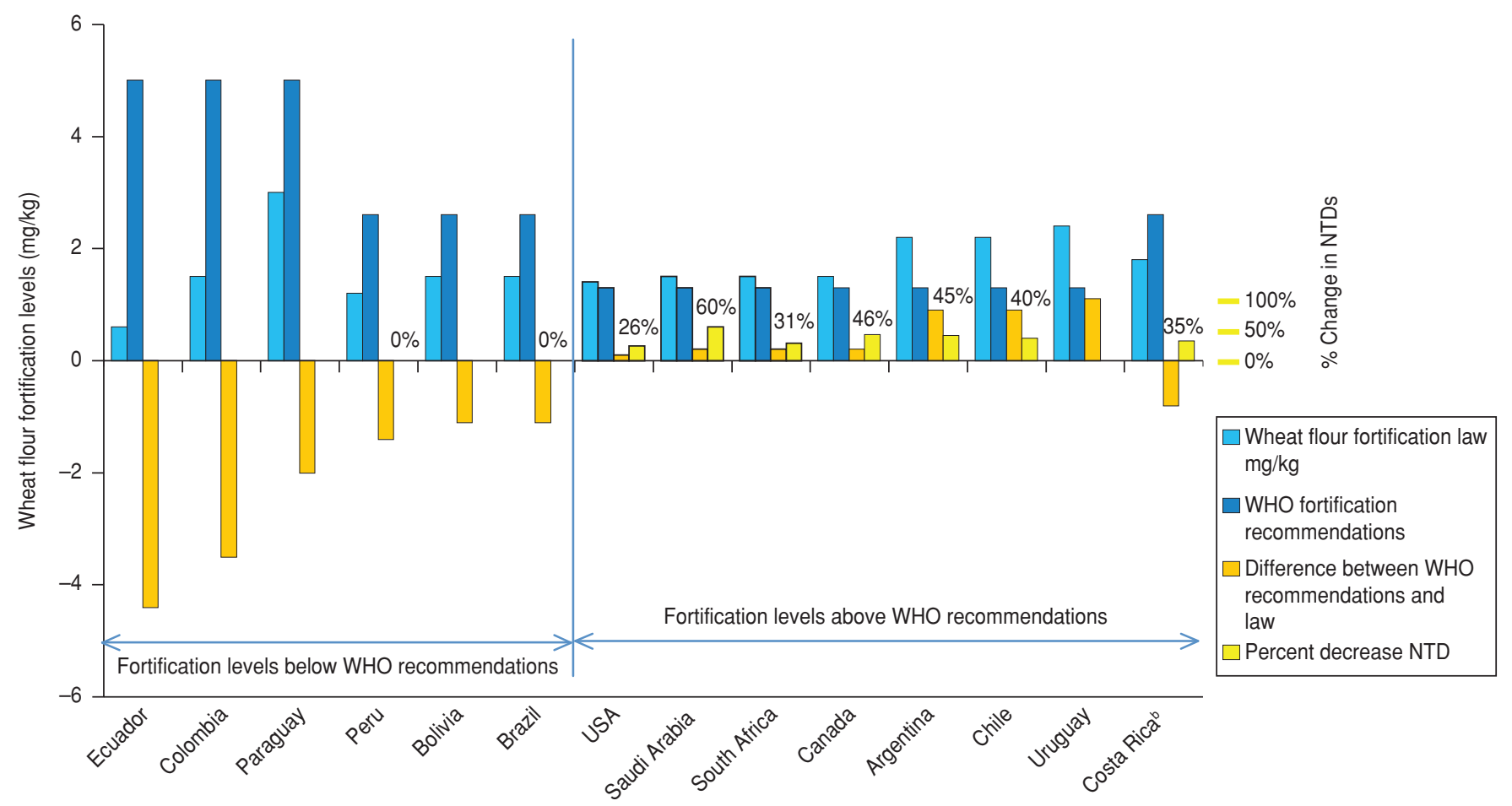

a Data based on current study results (Lima, 2005) and literature review $(5,11-17)$.

b Costa Rica law fortifies 4 food groups, delivering a total daily fortification above WHO recommended $400 \mathrm{mcg} / \mathrm{day}$. 
wheat flour $(1.8 \mathrm{mg} / \mathrm{kg})$; maize flour (1.8 $\mathrm{mg} / \mathrm{kg})$; rice $(1.8 \mathrm{mg} / \mathrm{kg})$; and milk $(0.4 \mathrm{mg} / \mathrm{kg})$. This requirement brings Costa Ricans' total daily consumption to an estimated $437 \mathrm{mcg} /$ day, yielding an observed decrease in NTDs of $35 \%$ (16).

Recommended fortification levels are determined by dietary habits rather than prevalence of NTDs. WHO recommendations vary by country based on per capita wheat flour consumption, with the goal of supplying $400 \mathrm{mcg}$ folic acid to the daily diet of women of childbearing age (24). For example, based on its wheat flour consumption, Saudi Arabia mandated a fortification level of $1.5 \mathrm{mg} / \mathrm{kg}$ (versus the $\mathrm{WHO}$ recommendation of $1.3 \mathrm{mg} / \mathrm{kg}$ ) to reach a sufficient level of folic acid in the diet to significantly reduce NTDs (11). Peru mandates only $1.2 \mathrm{mg} / \mathrm{kg}$ of fortification (versus the WHO recommendation of $2.6 \mathrm{mg} / \mathrm{kg}$ ) and has not reached the required levels of folic acid intake to decrease NTDs.

Red blood cell (RBC) folate studies in Peru show that prior to fortification, women were not receiving the necessary folic acid in their diets. Research in Lima revealed that $2.4 \%$ of women of childbearing years had an RBC folate level deficiency $(<140 \mu \mathrm{g} / \mathrm{L})$, with a median of $281 \mathrm{ng} / \mathrm{ml}$ and a mean of $306 \mathrm{ng} / \mathrm{ml}(33,34)$. While this may seem like a low prevalence of deficiency, it translated to more than 59000 women of childbearing age with folate deficiency in Lima. These results also mean that $50 \%$ of the population had RBC folate levels below $281 \mathrm{ng} / \mathrm{ml}$, far below WHO's recommendation of $400 \mathrm{ng} / \mathrm{ml}$, and the $576 \mathrm{ng} / \mathrm{ml}$ suggested by Daly (35), as the dose above which minimal benefit in preventing NTDs is seen.

There are several other risk factors for NTDs, such as genetic defects (1), obesity (36), various folate antagonist medications (37), green tea consumption (38), and vitamin B12 deficiencies (39). While all of these factors may contribute to the high rate of NTDs in Peru, until RBC folate levels are optimized, it must be assumed that 1) current fortification is inadequate and the necessary daily intake of $400 \mathrm{mcg}$ of folic acid is not being achieved, and 2) with correction of these folic acid deficits, Peru will see a decrease in NTDs, based on the results of other countries that have been studied.
The results of this study also challenge the notion that the relationship between folic acid fortification and NTD prevention is linear. Previous studies have established that while RBC folate levels respond linearly to additional consumption of folic acid, the decrease in NTDs plateaus with an RBC folate level of about $576 \mathrm{ng} / \mathrm{ml}(35,40)$. Therefore, it has been suggested that the doseresponse curve plateaus at this point, creating an upper therapeutic limit. This pattern is seen in the United States, which had a smaller benefit to fortification then that predicted by the linear model. The authors of the current study propose that prevention of NTDs follows the traditional S-shaped dose-response curve at low doses as well (i.e., at doses below the threshold dose, a minimal response would be observed), and that once the threshold dose is achieved, small increases in dose provide a large increase in therapeutic response. This could explain why Saudi Arabia saw a $60 \%$ decrease in NTDs. While the threshold dose for therapeutic response is unknown, this study suggests that there is a threshold dose that was not obtained in Peru.

Future studies are needed to further define the dose-response curve, to delineate where the threshold dose lies, and to clarify why women with the same RBC folate levels have varied clinical responses. At the international level, future research could help identify better ways to educate health care providers, administrators, and legislators to facilitate policy change.

In Peru, advocates for children can use evidence from this study indicating folic acid levels are low and maternal and infant complications are high to help inform other stakeholders that the legislation on fortification of wheat flour in Peru has not yet achieved its objectives.

\section{Conclusion}

This study confirmed that wheat millers are complying with Peru's fortification legislation but identified no significant change in the birth prevalence of NTDs at one large hospital in Lima pre- and post-fortification of wheat flour with folic acid. It also found that Peru and other countries are not fortifying their food products to the levels recommended by $\mathrm{WHO}$, and that Peru and Brazil may not be experiencing any decrease in their NTD rates. These results indicate some countries may be fortifying their food items with folic acid at levels below a threshold for improvement.

It is the responsibility of all public health policymakers to use the best available recommendations and data in directing the health policies of their respective countries. In the case of folic acid fortification, it is in the best interest of both population health and the national economy to ensure folic acid fortification to the levels recommended by WHO or higher. The level of fortification recommended by WHO appears to allow adequate folic acid intake to reach the threshold therapeutic dose for decreasing the birth prevalence of NTDs within a population. Public health policy should be adjusted to meet this daily nutritional goal to ensure that legislation will yield a measurable benefit. Policies mandating fortification below those threshold levels may be no better than no fortification at all.

NTDs remain a significant public health problem in Peru, increasing morbidity and perinatal mortality. NTD prevalence also has important implications in terms of the cost to the referral facilities providing NTD treatment and care. Already, national groups such as the Spina Bifida and Hydrocephalus Association of Peru (Asociación de Espina Bífida e Hidrocefalia del Perú, ASESBIH) and the Pediatric Society of Peru are advocating for this change. Therefore, despite the limitations of this study, Peruvian Ministry of Health officials should consider the evidence presented here on the need to increase folic acid fortification of wheat flour to international recommended levels $(2.6 \mathrm{mg} / \mathrm{kg})$ and thereby achieve higher levels of NTD prevention to reduce their impact on both child health and health care costs.

Acknowledgments. The authors thank Delmi Pino and ASESBIH for their untiring efforts to reduce NTDs in Peru and to provide care for children born with NTDs with dignity and compassion. 


\section{REFERENCES}

1. Bassuk AG, Kibar Z. Genetic basis of neural tube defects. Semin Pediatr Neurol. 2009;16(3):101-10.

2. Centers for Disease Control and Prevention (US). CDC Grand Rounds: additional opportunities to prevent neural tube defects with folic acid fortification. MMWR Morb Mortal Wkly Rep. 2010;59(31):980-4.

3. Oakley GP. The scientific basis for eliminating folic acid-preventable spina bifida: a modern miracle from epidemiology. Ann Epidemiol. 2009;19(4):226-30.

4. Botto LD, Moore CA, Khoury MJ, Erickson JD. Neural-tube defects. N Engl J Med. 1999:341(20):1509-19.

5. Centers for Disease Control and Prevention (US). Spina bifida and anencephaly before and after folic acid mandate-United States, 1995-1996 and 1999-2000. MMWR Morb Mortal Wkly Rep. 2004;53(17):362-5.

6. Cherian A, Seena S, Bullock, RK, Antony AC. Incidence of neural tube defects in the leastdeveloped area of India: a population-based study. Lancet. 2005;366(9489):930-1.

7. Blencowe $\mathrm{H}$, Cousens S, Modell B, Lawn J. Folic acid to reduce neonatal mortality from neural tube disorders. Int J Epidemiol. 2010;39 Suppl 1:i110-21.

8. Berry RJ, Li Z, Erickson JD, Li S, Moore $\mathrm{CA}$, Wang $\mathrm{H}$, et al. Prevention of neural-tube defects with folic acid in China. China-U.S. Collaborative Project for Neural Tube Defect Prevention. N Engl J Med. 1999;341(20):1485-90.

9. Bell KN, Oakley GP. Update on prevention of folic acid-preventable spina bifida and anencephaly. Birth Defects Res A Clin Mol Terato. 2009;85(1):102-7.

10. Botto LD, Lisi A, Bower C, Canfield MA, Dattani N, De Vigan C, et al. Trends of selected malformations in relation to folic acid recommendations and fortification: an international assessment. Birth Defects Res A Clin Mol Teratol. 2006;76(10):693-705.

11. Safdar O, Al-Dabbagh A, AbuElieneen WA, Kari JA. Decline in the incidence of neural tube defects after the national fortification of flour (1997-2005). Saudi Med J. 2007;28(8):1227-9.

12. Calvo EB, Biglieri A. Impacto de la fortificación con ácido fólico sobre el estado nutricional en mujeres y la prevalencia de defectos del tubo neural. Arch Argent Pediatr. 2008;106(6):492-8.

13. Pacheco SS, Braga C, Souza AI, Figueiroa JN. Effects of folic acid fortification on the prevalence of neural tube defects. Rev Saude Publica. 2009;43(4):565-71.

14. De Wals P, Tairou F, Van Allen MI, Uh SH, Lowry RB, Sibbald B, et al. Reduction in neural-tube defects after folic acid fortification in Canada. N Engl J Med. 2007;357(2):135-42.

15. Hertrampf E, Cortés F. Folic acid fortification of wheat flour: Chile. Nutr Rev. 2004;62(6 Pt 2):S44-8.

16. Chen LT, Rivera MA. The Costa Rican experience: reduction of neural tube defects following food fortification programs. Nutr Rev. 2004;62(6 Pt 2):S40-3.

17. Sayed AR, Bourne D, Pattinson R, Nixon J, Henderson B. Decline in the prevalence of neural tube defects following folic acid fortification and its cost-benefit in South Africa. Birth Defects Res A Clin Mol Teratol. 2008; 82(4):211-6.

18. Lijing Ouyang L, Grosse S, Armour B, Waitzman N. Health care expenditures of children and adults with spina bifida in a privately insured U.S. population. Birth Defects Res A Clin Mol Teratol. 2007;79(7):552-8.

19. Hertrampf E, Cortés F. National food-fortification program with folic acid in Chile. Food Nutr Bull. 2008;29(2 Suppl):S231-7.

20. Sanabria H, Tarqui C. Fundamentos para la fortificación de la harina de trigo con micronutrientes en el Perú. Anal Fac Med UNMSM. 2007;68(2):185-92

21. Hertrampf E, Cortés F, Erickson JD, Cayazzo M, Freire W, Bailey LB, et al. Consumption of folic acid-fortified bread improves folate status in women of reproductive age in Chile. J Nutr. 2003;133(10):3166-9.

22. United Nations Children's Fund. At a glance: Peru. Statistics [Internet]. New York: UNICEF; c2003. Available from: www.unicef.org/ infobycountry/peru_statistics.html Accessed 2 June 2010

23. Ministerio de Salud, Dirección General de Salud Ambiental (PE). Reglamento de la ley $\mathrm{N}^{\circ}$ 28314, que dispuso la fortificatión de la harina de trigo con micronutrientes [legal reform of Peruvian Law 28314]. June 25 2006. Lima: MINSA/DIGESA; 2006. Available from: www.inmetro.gov.br/barreirastecnicas/pontofocal/..\%5Cpontofocal\%5Ctextos \%5Cregulamentos\%5CPER_10.pdf Accessed 4 September 2010.

24. World Health Organization. Recommendations on wheat and maize flour fortification. Meeting report: Interim Consensus Statement. Geneva: WHO; 2009. (WHO/NMH/NHD/ MNM/09.1). Available from: www.who. int/nutrition/publications/micronutrients/ wheat_maize_fort.pdf Accessed 4 September 2010.

25. United States Department of Agriculture Foreign Agricultural Service. Peru grain and feed report 2010. Washington: USDA-FAS; 2010. Available from: http://gain.fas.usda.gov/ Recent\%20GAIN\%20Publications/Grain\%20 and $\% 20$ Feed\%20Annual_Lima_Peru_1-222010.pdf Accessed 4 September 2010.

26. Cheschier N; ACOG Committee on Practice Bulletins-Obstetrics. ACOG practice bulletin. Neural tube defects. Number 44, July 2003. (Replaces committee opinion number 252, March 2001). Int J Gynaecol Obstet. 2003;83(1):123-33.

27. American Academy of Pediatrics. Folic acid for the prevention of neural tube defects. American Academy of Pediatrics. Committee on Genetics. Pediatrics. 1999;104(2 Pt 1): 325-7.

28. Erickson JD. Folic acid and prevention of spina bifida and anencephaly: 10 years after the U.S. Public Health Service recommendation. MMWR Recomm Rep. 2002;51(RR13):1-3.

29. Delisle H. Patterns of urban food consumption in developing countries: perspective from the 1980s. Rome: Food and Agriculture
Organization; 1990. Available from: ftp:// ftp.fao.org/es/esn/nutrition/urban/delisle_ paper.pdf Accessed 19 August 2012.

30. Rose D, Burgos G, Bonierbale M, Thiele G. Understanding the role of potatoes in the Peruvian diet: an approach that combines food composition with household expenditure data. J Food Comp Anal. 2009; doi:10.1016/j. jfca.2008.10.002.

31. Tarqui-Mamani C, Sanabria H, Lam N, Arias J. Incidencia de los defectos del tubo neural en el Instituto Nacional Materno Perinatal de Lima. Rev Chil Salud Publica. 2009;13(2):82-9.

32. Heseker HB, Mason JB, Selhub J, Rosenberg $\mathrm{IH}$, Jacques PF. Not all cases of neural-tube defect can be prevented by increasing the intake of folic acid. Br J Nutr. 2009;102(2): 173-80.

33. Sanabria $H$, Velarde $P$, Zavaleta $N$, Kim $S$, Grajeda R, Sullivan K, et al. Evaluación basal de anemia por deficiencia de hierro y folatos en mujeres en edad fértil y niños de 24 a 59 meses en Lima Metropolitana. Lima: Organización Panamericana de la Salud; 2006. Available from: http://bvs.per.paho.org/SCT/ SCT2006-010/SCT2006010.pdf Accessed 13 March 2012.

34. Sanabria HA, Tarqui-Mamani C, Villanueva V. Importancia de fortificar la harina de trigo con ácido fólico para prevenir defectos del tubo neural en Perú. Rev Enferm Herediana. 2009;2(2):105-12.

35. Daly LE, Kirke PN, Molley A, Weir DG, Scott JM. Folate levels and neural tube defects. Implications for prevention. JAMA. 1995;274(21):1698-702.

36. Stothard KJ, Tennant PW, Bell R, Rankin J. Maternal overweight and obesity and the risk of congenital anomalies: a systematic review and meta-analysis. JAMA. 2009;301(6):636-50.

37. Matok I, Gorodischer R, Koren G, Landau D, Wiznitzer A, Levy A. Exposure to folic acid antagonists during the first trimester of pregnancy and the risk of major malformations. $\mathrm{Br}$ J Clin Pharmacol. 2009;68(6):956-62.

38. Alemdaroglu NC, Dietz U, Wolffram S, Spahn-Langguth $\mathrm{H}$, Langguth $\mathrm{P}$. Influence of green and black tea on folic acid pharmacokinetics in healthy volunteers: potential risk of diminished folic acid bioavailability. Biopharm Drug Dispos. 2008;29(6):335-48.

39. Ray JG, Wyatt PR, Thompson MD, Vermeulen MJ, Meier C, Wong PY, et al Vitamin B12 and the risk of neural tube defects in a folic-acid-fortified population. Epidemiology. 2007;18(3):362-6.

40. Brown JE, Jacobs DR Jr, Hartman TJ, Barosso GM, Stang JS, Gross MD, et al. Predictors of red cell folate level in women attempting pregnancy. JAMA. 1997;277(7):548-52.

Manuscript received on 16 April 2012. Revised version accepted for publication on 9 September 2012. 
RESUMEN Objetivo. Evaluar la repercusión que el programa nacional del Perú de fortificación con ácido fólico tiene en el contenido de ácido fólico de la harina de trigo y en la prevalencia de nacimientos de niños con defectos del tubo neural en Lima, así como

\section{Programa nacional del Perú de fortificación con ácido fólico y su efecto sobre los defectos del tubo neural en Lima}

comparar los requisitos legislativos del programa con las normas internacionales.

Métodos. Se hizo un muestreo del pan en seis zonas de Perú y se analizó su contenido de ácido fólico. Se obtuvieron datos del mayor hospital obstétrico de Lima referentes a la prevalencia de nacimientos de niños vivos o mortinatos con defectos del tubo neural durante el período anterior a la fortificación (2004-2005) y el posterior a la misma (2007-2008).

Resultados. El contenido de ácido fólico en las muestras de pan obtenidas satisfizo los requisitos legislativos nacionales, si bien fue inferior a la mitad de la concentración que la Organización Mundial de la Salud (OMS) recomienda para el Perú $(2,6 \mathrm{mg} / \mathrm{kg}$ de harina de trigo). La prevalencia de nacimientos de niños con defectos del tubo neural fue de 18,4/10 000 en el período anterior a la fortificación y de 20,0/10 000 en los años posteriores a la fortificación. El riesgo relativo de los defectos del tubo neural después de la fortificación fue de 1,02 (intervalo de confianza de 95\%: 0,77-1,35; $P=0,90)$.

Conclusiones. Los valores que la legislación peruana exige en lo que respecta a la fortificación con ácido fólico son inferiores a los que se recomiendan internacionalmente (OMS). La prevalencia de nacimientos de niños con defectos del tubo neural en Lima es superior a las cifras de referencia internacionales. Por otra parte, no se observó ninguna disminución de los defectos del tubo neural después de fortificar la harina con ácido fólico (según los valores normalizados nacionales peruanos). Dado que el aumento de la concentración de ácido fólico en la harina sigue siendo la manera más sostenible de prevenir los defectos del tubo neural, se recomienda que el Perú haga más estrictos los requisitos relativos a la fortificación con ácido fólico para ajustarse a los valores recomendados por la OMS $(2,6 \mathrm{mg} / \mathrm{kg})$.

Palabras clave Defectos del tubo neural; ácido fólico; alimentos fortificados; política social; Perú. 